\title{
Improvement of decompression unit in autonomous drug release system for blood sugar control
}

\author{
血糖値制御を目的とした自律駆動型薬物放出システムの高出力化に関する研究
}

\author{
Rei SATO, Kohdai HATAYAMA, Munkhbayar MUNKHJARGAL, Yuki MATSUURA \\ Graduate School of Medical and Dental Sciences, Tokyo Medical and Dental University, 2-3-10 Kanda- \\ Surugadai, Chiyoda-ku, Tokyo 101-0062, Japan
}

Takahiro ARAKAWA, Hiroyuki KUDO and Kohji MITSUBAYASHI

Institute of Biomaterials and Bioengineering, Tokyo Medical and Dental University 2-3-10 KandaSurugadai, Chiyoda-ku, Tokyo 101-0062, Japan

TEL: x81-3-5280-8091ＦAX: x81-3-5280-8094ｅ-mail:m.bdi@tmd.ac.jp

(Received 18 Febrary, $2013 \quad$ Accepted 18 April, 2013)

\begin{abstract}
Improvement of the decompression unit "Organic engine" that can generate kinetic energy from the chemical energy of chemicals such as glucose has been proposed and tested. The organic engine was fabricated by separating a cylindrical cell into a top-cell for gas-phase and a bottom-cell for liquid-phase, which separated by glucose oxidase immobilized membrane. Decompression was generated by catalysis of glucose oxidation. However, the concentration of glucose to actuate the system was $100 \mathrm{mmol} / \mathrm{L}$ that is too high compared to the human blood glucose concentration to apply it for artificial pancreas-like devices. In order to increase decompression rate, methods to enlarge area of the enzyme membrane per volume of the gas chamber were proposed and evaluated. Decompression rate in modified cell on $25 \mathrm{mmol} / \mathrm{L}$ glucose solution was equal to that of in conventional cell $\left(-7.2 \mathrm{~Pa} \cdot \mathrm{cm}^{3} / \mathrm{s}\right)$ on $100 \mathrm{mmol} / \mathrm{L}$ glucose solution. As a result, three times higher output was enable to actuate on low glucose concentration close to blood sugar.
\end{abstract}

Keywords : Organic engine, Chemo-mechanical system, Actuator, Glucose oxidase, Enzyme reaction

\section{INTRODUCTION}

生体内の血糖值制御では，膵蔵のランゲルハンス島に 存在する $\beta$ 細胞より血糖值に応じて分泌されるインスリ ンと $\alpha$ 細胞より分泌されるグルカゴンの作用により調節 される.インスリンは血糖值を低下させる唯一のホルモ ンであるため, 糖尿病患者はインスリン注射やインスリ ンポンプなど, 体外からのインスリン投与による血糖值 制御が必要となる。 ${ }^{1}$ 近年では, インスリンポンプに血糖 測定の情報をフィードバックし，インスリン投与量を自 動的に調整する人工膵蔵が開発されている. ${ }^{2}$ 一方, 酵素

SAS Award was given to this paper presented as Poster Presentation at the 2012 SAS Intelligent Symposium.
の触媒反応を人工的に制御することで，多様な生体成分 の化学エネルギーから直接駆動力を取り出す「有機エン ジン」が開発されている. ${ }^{3}$ 有機エンジンは, 酵素膜を隔 膜とし，気相セルと液相セルの間に挟み込んだ構造を有 し, 液相セルに基質となる溶液を送液することで, 酵素 の触媒反応に伴い気相セル内の酸素ガスの生成または消 費により，圧力変化を生じる。この酵素としてグルコー ス酸化酵素(glucose oxidase, GOD)を用いることにより, 血糖成分であるグルコースの化学エネルギーにて減压が 可能な「グルコース駆動型有機エンジン」を作製し，薬 物放出機構と組み合わせることで, グルコース濃度を低 下・安定化させる「薬物放出システム」が考案された.

4 しかしながら従来の系では, 薬物放出の動作に正常血糖 
值の約 20 倍以上である $100 \mathrm{mmol} / \mathrm{L}$ 程度のグルコース濃 度を要し, 生体での駆動には血糖レベルにて作動可能な ように，デバイスを高出力化する必要がある.

本研究では, 有機エンジンの構造を改良することで, 従来の $100 \mathrm{mmol} / \mathrm{L}$ のグルコースにて駆動していた減圧 機構の減圧効果を高め, 糖尿病患者での利用を目指した 血糖レベルでも薬物放出システムの駆動が可能な有機エ ンジンの開発を試みた。

\section{EXPERIMENTAL SECTION}

GOD の触媒反応(1)式に伴い気相セル内の酸素ガスの 消費により, 圧力変化を生じる. 減圧機構(有機エンジン) の出力は, 酵素膜における触媒反応により消費される酸 素の量に基づく.

$$
\text { glucose }+\mathrm{O}_{2} \stackrel{\mathrm{GOD}}{\longrightarrow} \text { gluconic acid }+\mathrm{H}_{2} \mathrm{O}_{2}
$$

従って, 酵素膜を大面積化することで反応面積を増加し, 酸素の消費を促進することで出力の向上が図れる.そし て酸素の消費が一定の時には，セル内圧の減少速度は容 積に依存する，そこで，単位容積あたりの酵素膜面積を 増加させるように減圧機構の構造を改良し, 高出力化を 試みた。

反応セルは，アクリル板 $(\mathrm{t}=10 \mathrm{~mm})$ をフライス加工に より, 気相セルの深さを従来の $6 \mathrm{~mm}$ から $1 \mathrm{~mm}$ に変更 することで容積を低減し, また酵素膜の面積を従来の $2.84 \mathrm{~cm}^{2}$ から $11.35 \mathrm{~cm}^{2}$ に増加させることで, 単位容積あ たりの酵素膜面積を増加させた気相並びに液相セルを作 製した. 改良型セルによる減圧機構の性能評価実験では, まず GOD を溶解させたリン酸緩衝液 $(\mathrm{PB}$, phosphate buffer) と酵素固定化用の紫外線硬化樹脂 PVA-SbQ の混合 溶液を透析膜上に塗布し, GOD を包括固定化し, GOD 酵 素膜を作製した. 次に，アクリル板を加工して作製した メッシュとシリコーン O リングで GOD 酵素膜を挟み

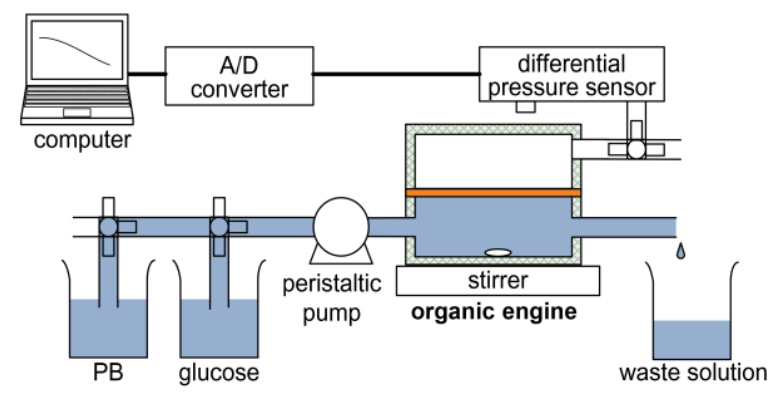

Fig. 1. Experimental setup to evaluate the potential of improved decompression unit.
込み，気相セル側に酵素固定化面となるよう改良型セル に取り付けることで減圧機構を構築した.評価実験では, 改良型減圧機構の気相セルに差圧計 (DMC-202N11, OKANO WORKS, LTD)を接続し，液相セルにPB を満た し 3 分間の圧力安定を確認した後，三方弁を用い，各濃 度のグルコース溶液を流量 $1 \mathrm{~mL} / \mathrm{min}$ にて液相セルへ送 液し, 気相セル内の圧力変化の関係を調べた(Fig. 1).

\section{RESULTS}

減圧機構の気相セルの深さを $1 \mathrm{~mm}$ とし, さらに, 酵 素膜の面積を従来の $11.35 \mathrm{~cm}^{2}$ とすることで, 単位容積あ たりの酵素膜面積を $3.0 \mathrm{~cm}^{2}$ とし, 従来型セルの約 4 倍 に増加させた。なお減圧機構の性能を酵素膜面積と気相 セル容量を考慮した減圧速度 $\left(\mathrm{Pa} \cdot \mathrm{cm}^{3} / \mathrm{s}\right)$ として算出した。 作製した改良型セルを使用した減圧機構について特性を 調べたところ， $25 \mathrm{mmol} / \mathrm{L}$ のグルコース濃度において減 圧速度が-7.2 $\mathrm{Pa} \cdot \mathrm{cm}^{3} / \mathrm{s}$ が得られた(Fig. 2). 改良型セルを 使用した減圧ユニットはグルコース濃度と減圧速度の間 に線形性を有しており, 従来に比べ, 約 3 倍の減圧能力 の向上が確認された. 反応セルの単位容積あたりの酵素 膜面積を大きくすることにより有機エンジンの高出力化 が可能となり，低濃度のグルコース溶液においてもシス テムの駆動が可能となった．今後さらに減圧機構の高出 力化を図ることで，血糖值レベルで駆動可能な薬物放出 システムの開発が可能と考えられる.

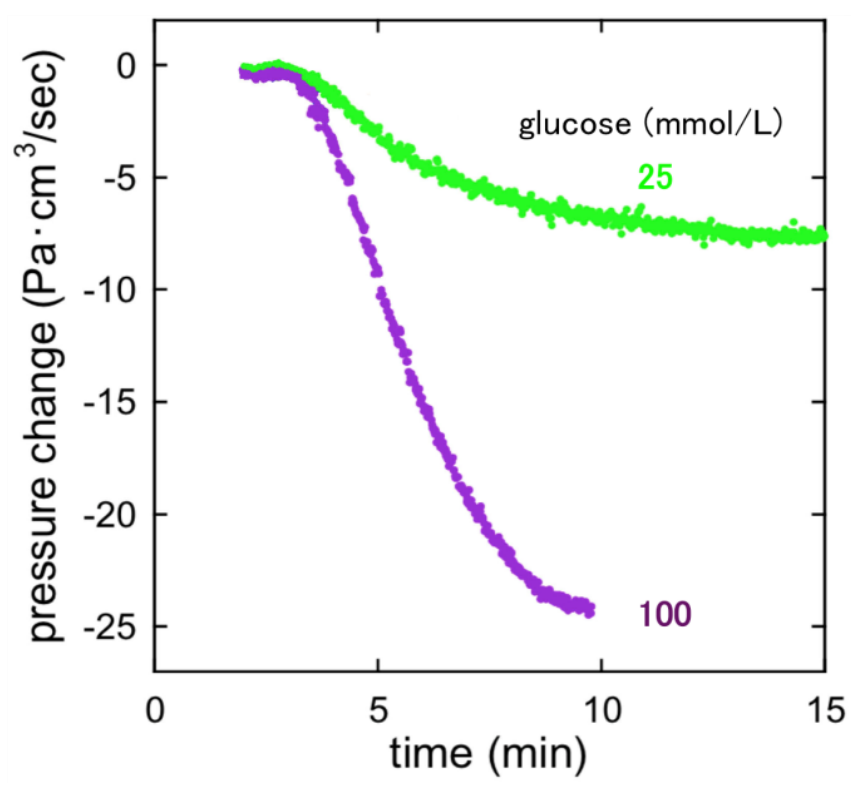

Fig. 2. Characteristics of decompression rate of improved decompression units. 


\section{CONCLUSION}

生体の血糖值レベルに近いグルコース濃度で減圧機構 を作動し, 反応セルの改良による減圧機構の高出力化を 罒った。 反応セルの最適化では，反応セルの構造を改良 し単位容積あたりの酵素膜面積を約 4 倍に増加させるこ とが可能となった. 以上の結果より，血液中の糖分をエ ネルギー源として, 糖尿病患者自身の血糖值を血糖モ二 タリングが不要で自律的に制御する薬物放出システムの 可能性が示唆された.

\section{ACKNOWLEDGEMENTS}

本研究の一部は, 日本学術振興会科学研究費補助金, 及び文部科学省特別教育研究経費「異種バイオサイエン ス技術の連携によるネオバイオロジ一推進基盤創生事業」 の助成により行われた。

\section{REFERENCES}

${ }^{1}$ C. R. Kahn, G. C. Weir, G. L. King, A. C. Moses, R. J. Smith, A. M. Jacobson, Eds. Joslin's Diabetes Mellitus, $14^{\text {th }}$ ed. Lippincott Williams \& Wilkins, 2004.

${ }^{2}$ B. W. Bequette, Challenges and recent progress in the development of a closed-loop artificial pancreas, Annual Reviews in Control 36, pp.255-266 (2012). ${ }^{3}$ K. Mitsubayashi, T. Ohgoshi, T. Okamoto, Y. Wakabayashi, M. Kozuka, K. Miyajima, H. Saito, H. Kudo, Biosensors and Bioelectronics, 24, pp. 15181521 (2009).

${ }^{4}$ R. Kato, M. Munkhjargal, D. Takahashi, T. Arakawa, H. Kudo, K. Mitsubayashi, Biosensors and Bioelectronics, 26, pp.1455-1459 (2010). 